\title{
THE IMPACT OF SOFT SKILLS OF PROJECT MANAGERS IN CONSTRUCTION PROJECT PERFormancE AS THE MEDiATION ROLE OF A CONCEPTUAL PROJECT RISK MANAGEMENT
}

\author{
Azman Hashim International Business School \\ University of Technology Malaysia (UTM) \\ Malaysia \\ nasseralsaadi2020@hotmail.com \\ Azman Hashim International Business School \\ University of Technology Malaysia (UTM) \\ Malaysia \\ aabdulkahar2@graduate.utm.my \\ and \\ Business School \\ University of Education, Winneba \\ Ghana \\ aka11@live.co.uk, akadam@uew.edu.gh
}

Nasser Salim Al Saadi

\section{Abdul-Kahar Adam*}

\section{Prof. Madya Dr. Norhayati Binti Zakuan}

Azman Hashim International Business School

University of Technology Malaysia (UTM)

Malaysia

norhayatimz@utm.my

*Corrosponding author's Email: aabdulkahar2@graduate.utm.my

Peer-review under responsibility of 4th Asia International Multidisciplinary Conference 2020 Scientific Committee

http://connectingasia.org/scientific-committee/

(C) 2020 Published by Readers Insight Publisher,

lat 306 Savoy Residencia, Block 3 F11/1,44000 Islamabad. Pakistan,

editor@readersinsight.net

This is an open access article under the CC BY-NC-ND license (http://creativecommons.org/licenses/by-nc-nd/4.0/). 


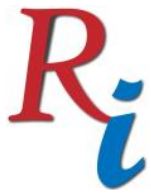

\section{Asia Proceedings of Social Sciences \\ (APSS) \\ www.readersinsight.net/APSS}

\section{A b s t r a c t}

This paper is a conceptual data presentation and analysis on the impact of soft skills of project managers in the construction industry as the target survey which is an improtant demand for construction of infrastructure and facilities around the globe since rapid economic development has increased. This study used a conceptual methodology approach based on qualitative analysis of theoretical research and empirical data. The review of literatures and discussions from previous studies showed that project management soft skills can be correlated with project risk management and project performance. It recommended future research of this topic quantitatively.

\section{Graphical A bstract}

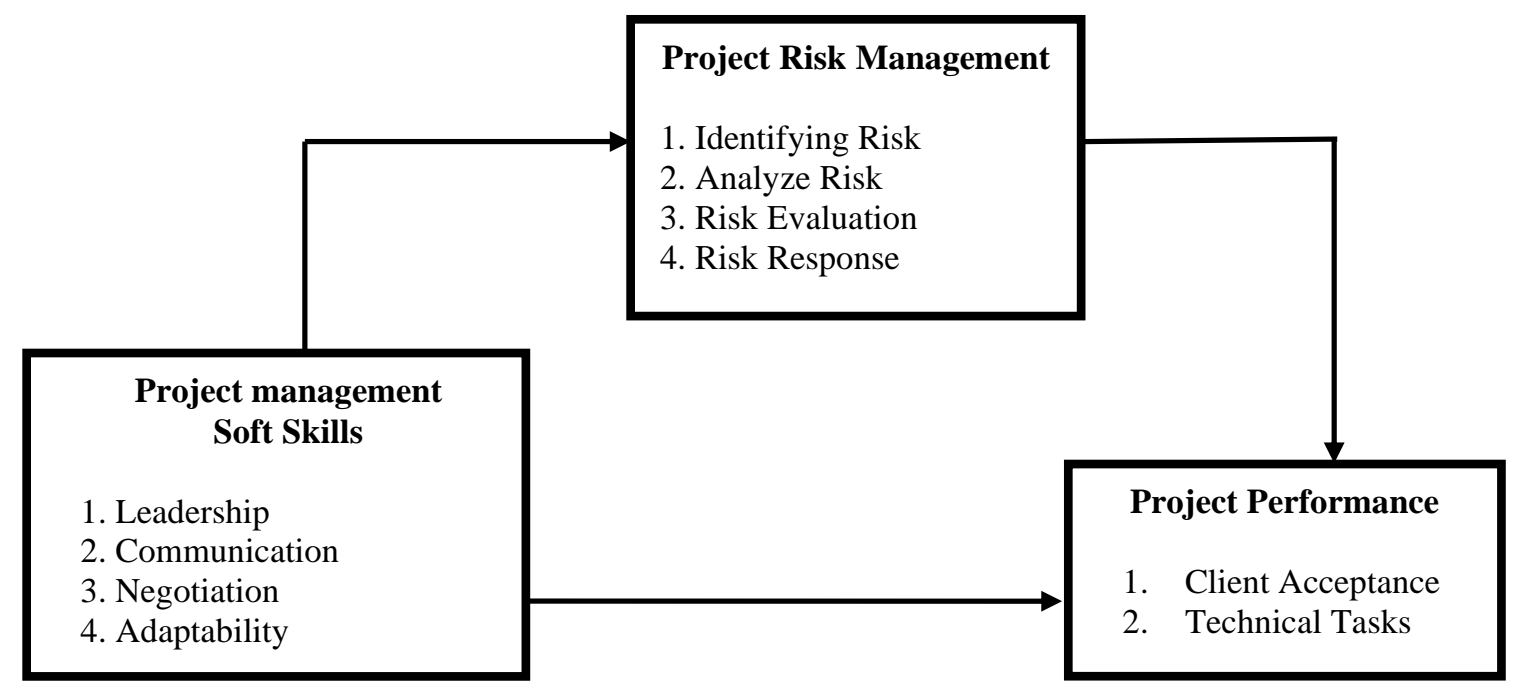

\section{Research Objectives}

This study was to examine the efect of project management soft skills on project performance as well as investigating the mediation role of conceptual project risk management on the association of project performance and project management of soft skills. The survey has been conducted in construction projects in Oman.. The results of this study is expected to support the economy of Oman by developing the performance of construction projects and reduce the level of potential risk by assigning qualified managers who can control the risk associated with these projects depending on soft skills. Since project success is the most discussed topic in project management, little is known about the influenc and success of project management. Eventhough there are vast array of project management literature and trainings available project management methodologies still fail to deliver consistent project success (Assem, 2018). Project success depends on a combined effect of soft skills and hard skills. 


\section{Methods}

The methodology used in this study is a qualitative study or explanatory based on causal research strategy. Qualitative research is subjective because its main concern is about evaluating the cause and effect of specific phenomena by collecting data empirically observed methods. The respondents are project managers in local construction companies in Oman. Thus, the total number of the population for this study as in the major thesis is 1187 project managers. As the researcher will not be able to test all population due to the limitation. The population sample of this research comprised solely of managers within selected number of construction companies in Oman. A qualitative method was adopted in a form of secondary sources of literature for this study as a conceptual paper.

\section{Research Findings}

The main significance of this study with regard to the mediating role of risk management is filling the gap in literature within construction projects as well as understanding the direct and indirect effect of soft skills of project managers. Inview of the above concepual framwork has been established. It is now important for future researchers to test the relationships to acertain their correlations with the necessary hypothesis. This study reveals that project management needs to be manage well in order to achieve good governance practice.

Haitham (2013) results showed that there is existence of impact between the skills of a manager of projects to deal with risk identification and risk assessment. The project manager must have certain skills to avoid potential risks associated with any project in a form of the technical knowledge and economic diverse (Vlădut, 2013). It is noted that risk management practices during the design phase influenced project performance. Different intelligent skills are considered important in different industries because, in the modern world, they are not just technical skills (Takey \& Carvalho, 2015). Kuen and Fernando (2009) stated that cleint acceptance is one of the success factors affecting the successfulness of project and without getting client acceptance the project will not be performed well.

\section{References}

Assem Al-Hajj and Mario M. Zraunig. (2018). The Impact of Project Management Implementation on the Successful Completion of Projects in Construction International Journal of Innovation, Management and Technology, 9(1), 21-27.

Haitham H. Al-Shibly, Basem M. Louzi, Mohammad A. Hiassat. (2013). The Impact of Risk Management on Construction Projects Success from the Employees Perspective. Interdisciplinary Journal of Contemporary Research in Business. Institute of Interdisciplinary Business Research 12. 5(4). 


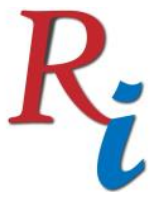

\section{Asia Proceedings of Social Sciences}

(APSS)

www.readersinsight.net/APSS

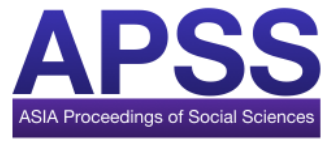

Kuen, C.W., Zailani, S., Fernando, Y. (2009), Critical factors influencing the project success amongst manufacturing companies in Malaysia. African Journal of Business Management, 3 (1), 16-27.

Vlăduț Severian Iacob. (2013). Studies and Scientific Researches. Economics Edition, 3(13).

Takey, S.M., Carvalho, M.M. (2015). Competency mapping in project management: an action research study in an engineering company. International Journal of Project Management. 33 (4), 784-796.

Author's Biography

Prof. Madya Dr. Norhayati Binti Zakuan is a Professor and Senior Lecturer at the Universiti Teknologi Malaysia, UTM in the Azman Hashim International Business School. She supervises a lot of PhD candidates in the faculty.

Nasser Salim Al Saadi is a PhD candidate at the Universiti Teknologi Malaysia, in the Azman Hashim International Business School, formerly called Faculty of Management.

Abdul-Kahar Adam is a PhD candidate at the Universiti Teknologi Malaysia, in the Azman Hashim International Business School, formerly called Faculty of Management. Abdul-Kahar is also a Lecturer in Ghana at the University of Education, Winneba, Ghana. 